\title{
NEWS OF ASSOCIATIONS
}

\section{Association for the Study of Nationalities}

On March 26, 1990, the Association, in conjunction with the Shevchenko Scientific Society (NY) and the Division of Humanities, The City College of New York, co-sponsored the inaugural session of the International Seminar for the Study of "Jews, Poles, and Ukrainians in their Historical Encounter."

Participants included:

Ivan Dziuba (Kiev University)

Regina Grol-Prokopczyk (SUNY-Buffalo)

Taras Hunczak (Rutgers University-Newark)

Henry R. Huttenbach (The City College of New York)

Andrzej Kaminski (Georgetown University)

Anatoly Pohribny (Kiev University)

David Roskies (Jewish Theological Seminary)

Leo Rudnytzky (La Salle University)

Stephen Velychenko (University of Toronto)

The conference was hosted by the W. Averell Harriman Institute for Advanced Study of the Soviet Union, Columbia University.

The conference proceedings will be published in a special issue of Nationalities Papers.

\section{The Jewish Historical Society (Moscow, USSR)}

Nationalities Papers has received the following announcements from the Jewish Historical Society, founded in February 1987. The Society has organized an international academic conference around the theme "The Historical Destiny of Russian Jewry" to be held in Moscow on 25 - 27 December, 1990.

For further information contact: Valery V. Engel, Chairman, 111395 Moscow, Snaiperskaya St. 5, Apt. 61, or Evgeny Y. Satanovsky, Secretary, 121293 Moscow, Pobedy Square 2, Building 1, Apt. 209.

\section{Hebrew University, Jerusalem, Israel}

The Marjorie Mayrock Center for Soviet and East European Research held an international conference "Environmental Problems and National Tensions in the Soviet Union" on January 2 - 4, 1990. 